University of Nebraska - Lincoln

DigitalCommons@University of Nebraska - Lincoln

University of Nebraska Press -- Sample Books

and Chapters

University of Nebraska Press

Fall 2011

Defying Maliseet Language Death

Bernard C. Perley

Follow this and additional works at: https://digitalcommons.unl.edu/unpresssamples

Part of the Arts and Humanities Commons

Perley, Bernard C., "Defying Maliseet Language Death" (2011). University of Nebraska Press -- Sample Books and Chapters. 79.

https://digitalcommons.unl.edu/unpresssamples/79

This Article is brought to you for free and open access by the University of Nebraska Press at DigitalCommons@University of Nebraska - Lincoln. It has been accepted for inclusion in University of Nebraska Press -- Sample Books and Chapters by an authorized administrator of DigitalCommons@University of Nebraska - Lincoln. 
Defying Maliseet Language Death 


\section{Buy the Book}




\title{
Defying Maliseet Language Death
}

\author{
Emergent Vitalities of Language, \\ Culture, and Identity in Eastern Canada
}

Bernard C. Perley

University of Nebraska Press | Lincoln and London 
(C) $201 \mathrm{I}$ by the Board of Regents of the University of Nebraska

All rights reserved Manufactured in the United States of America

A book in the Recovering Languages and Literacies of the Americas initiative. Recovering Languages and Literacies is supported by the Andrew W. Mellon Foundation.

Library of Congress

Cataloging-in-Publication Data

Perley, Bernard C.

Defying Maliseet language death: emergent vitalities of language, culture, and identity in Eastern Canada / Bernard C. Perley. p. $\mathrm{cm}$.

Includes bibliographical references and index. ISBN 978-0-8032-2529-9 (cloth: alk. paper) I. Passamaquoddy language-New BrunswickTobique Indian Reserve-History. 2. Passamaquoddy language-New Brunswick-Tobique Indian Reserve-Revival. 3. Language obsolescenceNew Brunswick-Tobique Indian Reserve. 4. Language and culture-New BrunswickTobique Indian Reserve. 5. Communication and culture-New Brunswick-Tobique Indian

Reserve. 6. Tobique Indian Reserve (N.B.)History. 7. Tobique Indian Reserve (N.B.)Social life and customs. I. Title. PM2I35.Z9T637 $201 \mathrm{II}$ $497^{\prime} \cdot 34-\mathrm{dc} 23$ 2011018952

Set in Quadraat by Bob Reitz. Designed by R. W. Boeche. 
To my grandmother.

Your spirit lives on.

To my mother.

Wisoki-woliwon 'ciw psi-te keq.

Koselomol. 


\section{Buy the Book}




\section{Contents}

Acknowledgments ix

Notes on Terminology and Orthography xiii

I. The Specter of Language Death I

2. "Tipping" toward Maliseet Language Death $3 \mathrm{I}$

3. Programming Language Maintenance 63

4. From Spoken Maliseet to Text 85

5. Elementary Language Curriculum and Practice IOI

6. Death by Suicide I2I

7. Language and Being in Maliseet Worlds $\quad$ I49

8. Emergent Vitalities of Language, Culture, and Identity $\quad$ I84

Notes 20I

References $2 \mathrm{I3}$

Index 225

Map

Tobique First Nation and the Maliseet homeland I3 


\section{Buy the Book}




\section{Acknowledgments}

This book would not have been possible without the generosity and the encouragement of many people. I have had the great fortune to have outstanding teachers, friends, and family throughout the duration of my research and the writing of this book. The strengths and gifts that come from this work I share with all of you. The weaknesses, errors, and omissions are mine alone.

I owe a great debt of gratitude to so many people at Tobique First Nation. This book would not have been as rich without the support and participation by all the wonderfully complex personalities who exchanged ideas and opinions with me. A special thank-you goes to Sandra and Timmy for accepting this nosey anthro into their lives. Many thanks go to the staff of Mah-Sos School for their kindness and teasing. I also thank David Perley and Andrea Bear Nicholas for their conversations about Maliseet language and culture. Thanks go to former chief Stewart Paul for his support of my research and his insights on Maliseet language, history, and culture. I had the best of fieldwork scenarios. I was able to enjoy the lively bantering and laughter among relatives and family while playing cards and attempting to speak Maliseet. Thank you to all my aunts, uncles, and cousins for putting up with my stupid questions and cross-linguistic puns. Thank you all for repatriating a native son (even if he is an anthropologist!). 
Special acknowledgment goes to David Maybury-Lewis, who passed away in the fall of 2007. David had been an extremely supportive mentor for me while I found my voice in anthropology. His quiet and patient guidance helped me make the transition from graduate school to professional practice. His work and dedication to indigenous cultural survival continues in my work and the work of colleagues he has inspired through his teaching, mentoring, and advocacy.

Many colleagues have made critical contributions to this work. From my graduate days. Steve Caton was a sharp critic and enthusiastic supporter of my intellectual explorations. Ronald Niezen encouraged and supported my exploration of the possibilities of Native American sovereignty in international relations. Robert Preucel was and continues to be a great friend and colleague. We have grappled with issues of repatriation and Native American self-determination. We have also promoted collaborative projects between anthropologists and Native American communities. Ruby Watson has been consistently interested and supportive of my work. Kay B. Warren has been an untiring advocate and confidant for me. Michael Herzfeld was generous in his willingness to provide lively conversation, professional advice, and friendship. James Watson and James Lorand "Randy" Matory were important professional development mentors who helped make my transition from student to assistant professor much less awkward. Thank you all for your friendship and tutelage.

Mentorship does not end in graduate school. My colleagues at the University of Wisconsin-Milwaukee (UWM) continue to provide me with mentorship, friendship, and critical debate. Special thanks go to Cheryl Ajirotutu for her unwavering support for my projects, be they writing, painting, or graphic novels. Thanks go to the Center for 2Ist Century Studies for a much needed year of critical "thinking and conversation."

In addition to my UWM colleagues I have had the great fortune to meet some remarkable scholars and truly generous people. I owe a great debt to Regna Darnell for her engaged and critical discussions 
on Native American languages and identity politics. I am grateful for her friendship and generous professional advice. Paul V. Kroskrity has been and continues to be a generous colleague in mentoring a junior scholar through professional development but also in engaging in critical language and cultural issues in Native North America. Frederic Gleach has been and continues to be a great friend and colleague whose unfailing support of my work is greatly appreciated. Thank you Laura Graham for your enthusiastic support of my work and the energy you bring to sharing ideas and solutions. Through the years, so many individuals have helped me explore the complexities between language and culture in Native North America. But it all started when Joel Sherzer predicted many years ago that I would be doing this work for the rest of my life. Thank you all for your continued support and friendship. Sincere thanks go to the anonymous readers of the manuscript, whose critical as well as supportive comments made this a better ethnography.

Many of the strategies for thinking through anthropology and language and how they can benefit Native American communities today came from lengthy discussions I had with fellow Native American scholars at Harvard University. Angela Gonzales, Gabrielle Tayac, Valerie Lambert, Phyllis Fast, and Darren Ranco were co-conspirators in our many activities to promote Native American programs at Harvard. Thank you all for your friendship and inspiration. I also had the good fortune to have a true friend in Sharri Clark, who gave me moral support when things seemed to be unraveling. Thank you Sharri for helping me keep things in perspective. We Native American students were fortunate to have Inés Talamantez as our mentor. Many thanks go to Inés for providing us with courage and determination as we worked to champion Native American perspectives in academia.

Words cannot adequately express the depth of gratitude I feel toward the people closest to my heart. Although she is long departed, I owe so much to my grandmother. Mimi, wisoki-woliwon. Thank you for your guidance. Mom, wisoki-woliwon 'ciw psi-te keq. You are the inspiration 
xii | ACKNOWLEDGMENTS

behind all my gifts. I continue to learn from you about life and love. My brothers Gilbert, Wendell, Leon, James, and John have been more than brothers. Thank you guys for many years of great friendship. Thank you also for your unquestioning and unreserved support. My accomplishments are yours too. I thank my dear friend and trusted wife for her keen mind and generous heart. Tracey, thank you for all your tough questions and keen insights. Thank you for all the time you invested in finding errors in grammar, argument, and exposition. Thank you for your encouragement when this project seemed unmanageable and interminable. Most of all, thank you for making my life rich beyond what words can ever express. Thank you, beloved partner. Koselomol. 


\section{Notes on Terminology and Orthography}

\section{Terminology}

This ethnography uses the terms aboriginal and its derivatives interchangeably with Native American and American Indian as the context of the discussion requires. The Canadian context favors aboriginal and aboriginality to refer to the indigenous peoples of Canada. American Indian and Native American are more commonly used in the United States when referring to the indigenous peoples within its borders. Canadian aboriginal peoples also prefer the political designation of First Nation when referring to the reserves or reservations. Reserve is the prevalent word used in Canada, while reservation is used in the United States. I use them interchangeably as the context of the discussion requires. "Indian" is sometimes used within quotes or where the context requires its use for consistency. I have used pseudonyms for all members of Tobique First Nation, the only exceptions being my immediate family members. There is no logic behind the pseudonyms assigned to Tobique community members. I apologize in advance for any perceived innuendo or insult, which I promise is unintended.

\section{Orthography}

The orthographic representation in this book is inconsistent and contradictory, and it is necessarily so. In this ethnography my goal is to 
represent the ethnographic material faithfully despite apparent inconsistencies and contradictions. As an ethnographer, I find that "correct" language usage and spelling are context and moment dependent. My goal is to understand why some representations are used instead of others and why community members change their minds.

There is a standardized orthography that has been developed since the Ig6os work of Teeter, the ' 70 s work of LeSourd, and important collaborative work of the Micmac-Maliseet Institute (Francis and Leavitt 2008:40). Today the standardized orthography is gaining popular acceptance at Tobique First Nation, but during my fieldwork (mid-I9gos) that was not the case. A number of orthographic representations were competing for general acceptance by the community. Most of the Maliseet texts used in this ethnography come from the Mah-Sos Elementary School language program, and therefore I use the orthography used in the classroom. The orthographic system in the school also changed, which contributes to inconsistencies in orthographic representation. Given the orthographic variety, I use the appropriate orthography when I use examples from other Maliseet language programs and their respective publications. 